\title{
The Impact of Individual Relationships on Performance and Reformation of R\&D Alliances
}

\author{
Alba Sánchez-Navas ${ }^{1}$, Xavier Ferràs-Hernández $^{2}$ \\ ${ }^{1}$ Facultat d'Economia i Empresa - Universitat de Barcelona (Spain) \\ ${ }^{2}$ Universitat de Vic - Universitat Central de Catalunya (Spain) \\ albasa15@gmail.com,xavier.ferras@,wic.cat
}

Received: June 2015

Accepted: September 2015

\section{Abstract:}

Purpose: To examine how trust, conflict, commitment and communication affect R\&D alliance performance, the individual's satisfaction with the alliance and their intention to collaborate with the same partners in the future.

Design/methodology/approach: Empirical research.

Findings: Trust, conflict, commitment and communication are positively related to alliance performance, although trust and communication are the characteristics with the strongest fit. In addition, successful alliances influence positively on individual satisfaction and raise the willingness to reform the alliance with the existing alliance members.

Originality/value: This study has enriched current understanding of the relationship among individual relations, alliance performance and reformation in R\&D alliances.

Keywords: R\&D alliances, performance, individual relations, reformation, satisfaction, trust, conflict, commitment, communication 


\section{Introduction}

There are strong theoretical streams dealing with alliance building and trying to explain the motivation behind cooperative behavior. Williamson (1985), but also Porter (1990) or Hamel, Doz and Prahalad (1989) analyze the sense making of cooperation and alliances regarding competitiveness and cost effects.

From a broad review of the innovation literature, we can distinguish two different waves of academic interest in alliances. The first wave of studies drew upon the network approach emerging from anthropology and sociology, and it is focused on the communicative interactions between individuals. There are three research areas that continue to resonate in the literature today related to this wave. The first area, centered on the communication networks of scientists (Price \& Beaver, 1966; Crane, 1969); the second, focused on the interaction of researchers in R\&D departments (Allen, 1970; Lin, Wu, Chang, Wang \& Lee, 2012); and the third one, concerning the diffusion, adoption, and adaptation of innovation by individuals (Rogers, 1995).

From the late 1980s, a second wave of research appeared. This second wave embraces a resurgence of the interests of the first wave, which is concerned on the interactions and relationships between individuals, but it is characterized by its focus on the exchanges and linkages between organizations (Powell, Koput \& Smith-Doerr, 1996; Håkansson, 1987; Burt, 1980). Last years, part of this trend has also looked at the effect of individual relationships such as trust, commitment or conflict on the strategic goals on alliance performance in a separate way (Cullen, Johnson \& Sakano, 2000; Luo, 2008; Perry, Sengupta \& Krapfel, 2004; Das \& Teng, 1998; Nielsen \& Nielsen, 2009; Jiang, Jiang, Cai \& Liu, 2015).

The object of study in this research is focused in a particular form of alliance, R\&D alliances. There has been an increasing number of studies about these alliances because of their specific features and their unique coordination challenges. (Hagedoorn, 2002; Tyler \& Steensma, 1995; Belderbos, Carree \& Lokshin, 2004). R\&D alliances usually require some sharing or transfer of knowledge over firm boundaries (Sampton, 2007), and moreover, they are rigid structures of collaboration that may suffer dynamic inefficiencies during the development of novel technologies, products or processes. These unique conditions in R\&D alliances may result in an increase of importance of individual relationships, which take an important role in the achievement of goals of the alliance.

Regarding the effect of relationships in R\&D alliances, literature provides conceptual models focused on relationships between organizations (e.g. Lin et al., 2012), and some authors such as Gulati (1998) or Heimericks (2002) mentions the impact of embedded ties on alliance performance and defines embeddedness as a matter of trust building, conflict management, personal responsibility and communication, but they are not applied empirically to the individual level in an integrated way. 
The objective of the present research is to study how individual relationships (in terms of trust, commitment, conflict and communication) explain alliance performance, satisfaction and the intention to reform the R\&D alliance in the future. We take up samples in $R \& D$ alliances to empirically test the model and hypotheses through a questionnaire survey taken by 261 individuals participating in these alliances. These results will enrich current understanding of the relationship among individual relations, alliance performance and reformation in R\&D alliances.

\section{Theory Foundation and Research Hypotheses}

\subsection{Trust and Alliance Performance}

Management literature shows the discussion of relationships in alliances frequently reduced to the role of trust (e.g. Das \& Teng, 1998; Krishnan, Martin \& Noorderhaven, 2006; Suseno \& Ratten, 2007; Jiang et al., 2015) and affirm that trust and trust building is based on positive expectations regarding other people intentions and behaviors in vulnerable situations like R\&D alliance where uncertainty is high (Clegg, Unsworth, Epitropaki \& Parker, 2002; De Jong \& Woolthuis, 2008; Das \& Teng, 2000).

Trust as a behavioral construct to deal with risk has been investigated in several studies dealing with interfirm innovation alliances (De Jong \& Woolthuis, 2008; Clegg et al., 2002; Cumbers, Mackinnon \& Chapman, 2003; Panayides \& Venus, 2009; Wang and Chen, 2007). Moreover, some results show that cooperation by itself, but even more in innovation alliances, requires trust as a relational asset that keeps the interfirm network together (Cumbers et al., 2003).

In spite of empirical evidence between trust and innovation alliances, some authors make their point on the intensity of trustful relationships arguing that "too much trust is death to innovation" (Bidault \& Castello, 2010). Based on the findings Levin and Cross (2004) research confirms that strong ties encouraged by trust generates knowledge transfer, but that actually weak tie relationships delivered the most useful knowledge.

Taking into account the role of trust in vulnerable situations, the impact of trustful relations on innovation processes should be positive. This is also confirmed by Maurer (2010), who sees a positive effect of trust on knowledge acquisition and therefore on product innovation also. Nielsen and Nielsen (2009) had similar results when analyzing the impact of trust on learning and tacit knowledge sharing on innovation in strategic alliances. In the same direction go Panayides and Venus (2009) who analyzed trust benefits on innovation and supply chain performance. On the basis of the above rationale, we propose: 
Hypothesis 1: Trust between partners in R\&D alliances is positively associated with alliance performance.

\subsection{Conflict and Alliance Performance}

Conflict can be defined as an awareness on the part of the parties involved of discrepancies, incompatible wishes, or irreconcilable desires (Boulding, 1963). One of the first approaches to study conflict was made by authors that distinguished functional and dysfunctional conflict (Anderson \& Narus, 1990; Reve \& Stern, 1979; Morris \& Cadogan, 2001) and have considered conflict as an unhealthy behaviour between partners that decrease teams' performance.

Later on, Jehn and Mannix (2001) propose that conflict in work groups can be categorized into three types-relationship, task, and process conflict. Relationship conflict involves personal issues such as dislike among group members and feelings such as annoyance, frustration, and irritation; task conflict pertains to conflict about ideas and differences of opinion about the task (Amason \& Sapienza, 1997), and finally, more recent studies have proposed a third kind of conflict, process conflict (Jehn, 1997; Jehn, Northcraft \& Neale, 1999) that refers to controversies about aspects of how task accomplishment will proceed. All this literature about conflict concludes that is a decreasing factor for groups' performance (e.g. Yi, Lee \& Dubinsky, 2010). Focusing on these studies we predict that:

Hypothesis 2: Conflict between partners in R\&D alliances is negatively associated with alliance performance.

\subsection{Commitment and Alliance Performance}

Many authors have analysed commitment from several perspectives: its influence on customers' satisfaction (Ganesan \& Hess, 1997), the role of commitment as an indicator of "relationship quality" together with trust and satisfaction measures (Walter, Muller, Helfert \& Ritter, 2003), a result of strategic purposes together with asset specificity (Sheth \& Parvatiyar, 1992), and from a resource-based view, commitment allows the continuity and long-term results of alliances (Gundlach, Achrol \& Mentzer, 1995; Wu \& Cavusgil, 2006; Nakos \& Brouthers, 2008).

Considering that competitive alliances and collaborative ventures, like R\&D alliances, demand a high degree of commitment because of the high entry barriers and, typically, low exit barriers (Sheth \& Parvatiyar, 1992) and is required to ensure successful relationships (Morgan \& Hunt, 1994), we propose that: 
Hypothesis 3: Commitment between partners in R\&D alliances is positively associated with alliance performance.

\subsection{Communication and alliance performance}

Communication behavior can be divided into three main aspects: communication quality, information sharing, and participation (Mohr \& Spekman, 1994). Communication quality is a key aspect of information transmission (Jablin, Putnam, Roberts \& Porter, 1987) and includes aspects such as the accuracy, timeliness, adequacy, and credibility of information exchanged (Lengel \& Daft, 1988; Stohl \& Redding, 1987). Information sharing includes the extent to which critical information is communicated to partners and it is related to the degree of effectiveness, satisfaction and success in a relationship (Guetzkow, 1965; Schuler, 1979; Devlin \& Bleackley, 1988). Finally, participation means the degree to which partners engage jointly in planning and goal setting, and it is also related to partnership's success (Anderson, Lodish \& Weitz, 1987; Dwyer, Schurr \& Oh, 1987).

Later on, Butler (2010) discovered that the quality of communication may differ within the firm as well as between the alliance partners, and that this will have an impact on the decisionmaking process in the alliance. Therefore, we predict that:

Hypothesis 4: Communication between partners in R\&D alliances is positively associated with alliance performance.

\subsection{Alliance Performance and Satisfaction}

As an emotional state of being, satisfaction has different facets depending on the contextual framework. Management research on satisfaction emphasizes strongly on employee-employer relationships (Malik, Ahmad, Saif \& Safwan, 2010; Singh \& Dubey, 2011; Shipton, West, Parkes, Dawson \& Patterson, 2006; Sharma, Bajpai \& Holani, 2011) and from the marketing area where customer satisfaction is the key concern of research (Fornell, Rust \& Dekimpe, 2010; Luo, Homburg \& Wieseke, 2010).

Satisfaction is "a post-decision evaluation of a product or an experience" (Oliver, 1996), which shows that satisfaction is a backward oriented construct, which affects the strength of a relationship, and, in our case, it will be directly related to the experience of getting or not satisfactory alliance performance. In fact, most of the empirical research in the field uses satisfaction as an observable variable to measure alliance performance due to the lack of other valid data (Saxton, 1997; Zollo, Reuer \& Singh, 2002). Therefore, we propose that: 
Hypothesis 5: Alliance performance is positively associated with partners' satisfaction with the R\&D alliance.

\subsection{Satisfaction and Reformation}

There are four possible outcomes for an alliance: stabilization, reformation, decline, and termination (Das \& Teng, 2000). Our object of study is analyzing the effect of alliance performance and partners' satisfaction on the decision of reforming the alliance for future R\&D projects.

According to the theoretical model of Das and Teng (2000), when alliance performance matches expectations, partners become more satisfied with the alliance, and thus, if partners continue having goals in common and the initial match between the partners is still sustainable, they may decide to reform the alliance. Therefore, we predict that:

Hypothesis 6: Satisfaction is positively associated with the intention of reforming the $R \& D$ alliance.

\section{Methods}

\subsection{Research Framework}

In this chapter, we develop a comprehensive research model based on a series of literature review. Based on the research framework, the hypotheses are developed to describe and verify the relationship among individual relationships, alliance performance, satisfaction and the intention of reform the alliance. The research framework is shown in Figure 1.

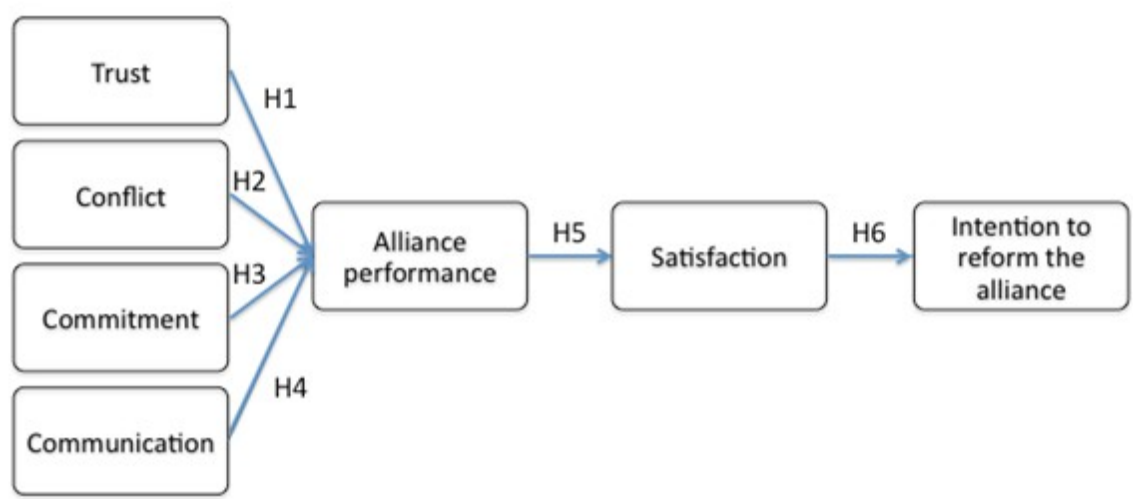

Figure 1 . The research model 


\subsection{Variable Definitions}

\subsubsection{Dependent Variables}

We measured three dependent constructs with a 5-point Likert scale system with 5 equaling the highest extent or degree. Constructs measured were alliance performance, satisfaction and reformation.

Alliance performance was measured through five items that have been adapted from existing articles of alliance performance studies, some measures that consider that the company achieves learning objectives (Geringer \& Hebert, 1991; Saxton, 1997; Lane \& Lubatkin, 1998; Dyer, Kale \& Singh, 2001; Kale, Dyer \& Singh, 2002); and some measures based on market gains (Anand \& Khanna, 2000; Merchant \& Schendel, 2000). Concretely, items measured are: "Technological knowledge acquired", "Creation of new technological opportunities", "Creation of new marketing opportunities", "New relationships and contacts" and "Achievement of initial objectives".

The second dependent variable, individual alliance participants' satisfaction with the R\&D project, was measured with a five-item scale (Van der Vegt, Emans \& Van de Vliert, 2001; Jehn et al., 1999): "I am satisfied with my present colleagues", "I am pleased with the way my colleagues and I work together", "I am very satisfied with working in this team", "How well do you think your group performs" and "How effective is your work unit?"

Finally, the intention to reform the alliance again in the future (reformation) with partners in the alliance with the question: "Would you like to collaborate in the future with any of the alliance partners?".

\subsubsection{Independent Variables}

Four exogenous items have been taken into account to predict our dependent variables: trust, conflict, commitment and communication. Also for independent variable a 5-point Likert scale system was used in the survey.

To get trust measures, we used questions adapted from McAllister (1995):" I can talk freely to my team about difficulties I am having at work and know that my team will want to listen", "I would feel a sense of loss if one of us was transferred and we could no longer work together", "If I shared my problems with my team I know she would respond constructively and caringly", "I would have to say that we (my alliance) have made considerable emotional investments in our working relationships", "Most of my partners approach his/her job with professionalism and dedication", "I see no reason to doubt my partners' competence and preparation for the job", "I can rely on other partners not to make my job more difficult by careless work" and "Most of 
my partners can be relied upon to do as they say they will do". These items all loaded on one factor, and the Cronbach's coefficient alpha for this scale was .813.

Following Jehn and Mannix (2001), we measured conflict at the alliances covering the three conflict categories. Items included "How much relationship tension is there in your work group?", "How often do people get angry while working in your group?", "How much emotional conflict is there in your work group?", "How much conflict of ideas is there in your work group?", "How frequently do you have disagreements within your group about the task of the project you are working on?", "How often do people in your work group have conflicting opinions about the project you are working on?", "How often are there disagreements about who should do what in your work group?", "How much conflict is there in your group about task responsibilities?" and "How often do you disagree about resource allocation in your work groups?". The Cronbach's alpha for this scale was .909.

The construct commitment consists on 5 items adapted from measures of commitment between suppliers and customers by Walter et al. (2003): "We focus on long-term goals in this relationship", "We are willing to invest time and other resources into the relationship with these partners", "We put the long-term cooperation with this partner before our short-term profit", "We expand our business with these partners in the future" and "We defend these partners when outsider criticizes the company". The factor analysis shown a one-factor resolution, and the reliability of this scale was .825 .

Finally, to assess communication behavior, we followed a procedure of Mohr and Spekman (1994), who used 5 items to measure the extent do you feel that your communication with partners was: "Timely/untimely", "Accurate/inaccurate", "Adequate/inadequate", "Complete/incomplete" and "Credible/ not credible". Cronbach's coefficient alpha for communication was .918.

\subsection{Research Samples and Measurement}

The object of the study is 119 R\&D alliances started from 2007 to 2009 in the region of Catalonia (Spain) and with 2 years of duration regulated by a collaboration contract.

Most of these R\&D alliances are concentrated in 3 technological sectors: $32.8 \%$ mobility (automotive, railway and aeronautical), $16.0 \%$ health, and $15.8 \%$ energy or environment as well. The 119 projects had the participation of 408 companies and 852 people directly involved in the R\&D alliances.

In our study, we used data from a survey among the individuals involved in these R\&D alliances that we conducted during 2011, when they had already finished. This approach was chosen to allow for a large-sample analysis of cross-sectional qualitative data. In order to 
minimize misinterpretation of questions, the questionnaire was pre-examined by several managers in industry and government officials who have coordinated R\&D alliances.

The final sample included 261 individuals out of 852 participating in alliances, for a final response rate of 30.6 percent.

\section{Results}

The model was tested using EQS and constructs trust, commitment, conflict and communication are treated as exogenous, while alliance performance, satisfaction and reformation were endogenous.

The overall fit of the model was good $[X 2(647)=1541.559, p=.000]$. Even though the probability was not greater than 0.10 , applying conventional guidelines, the chi-square index was less than twice the degrees of freedom, indicating a reasonable good fit. The chi-square statistics is based on the assumption that the model holds exactly in the population, which would be unrealistic in most empirical research (Joreskog, 1993).

Therefore, it is important to also assess a model using root mean square error of approximation (RMSEA), which is a measure of discrepancy per degree of freedom and is useful in assessing the degree of approximation in the population (Joreskog, 1993). A RMSEA of 0.079 indicates a close fit. Also the comparative fit index (CFI) was 0.822 and indicates a good fit. The goodness-of-fit index and the adjusted goodness-of-fit were 0.739 and 0.701 , respectively. Finally, the standardized root mean square residual was 0.076 .

The Bentler-Bonett normed fit index (NFI) was .831 and the Bentler-Bonett not-normed fit index (NNFI) was .807 , both indicate a good estimation of our model.

Results of our structural equation model (SEM) are presented in Figure 2.

Recall that in hypotheses 1,3 and 4 we predicted that trust, commitment and communication would be positive related to alliance performance. The SEM result results support these hypotheses. The three constructs were positively associated with alliance performance. The effect on alliance performance is especially high in trust $(b=0.32, p<0.001$ ) and communication ( $b=0.54, p<0.001)$, although commitment has a positive effect as well $(b=$ $0.17, \mathrm{p}<0.05)$. However, hypothesis 2 was rejected as we found that conflict was also positively related to alliance performance $(b=0.23, p<0.001)$.

Finally, our model supports the relationships between alliance performance, satisfaction and reformation. The model shows a positive effect from alliance performance to satisfaction $(b=$ $0.42, p<0.001$ ), which supports hypothesis 5 , while satisfaction have a modest effect on reformation $(b=0.115, p<0.05)$. Thus, hypotheses 5 and 6 are supported by SEM results. 


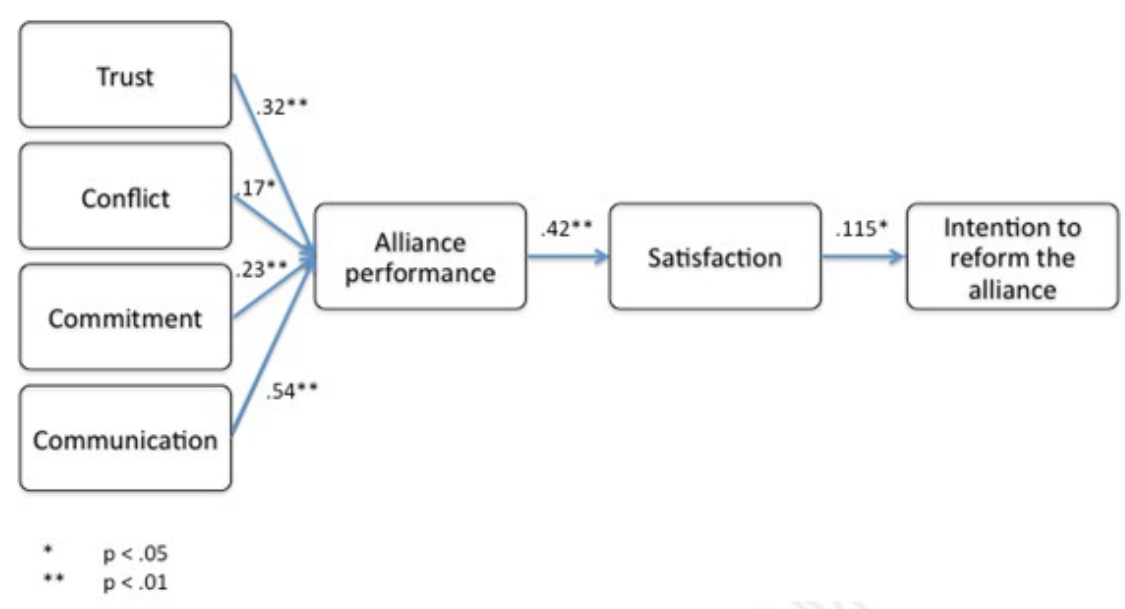

Figure 2. Effect of individual relationship on alliance performance, satisfaction and reformation of the alliance

\section{Conclusion and Implication}

In extension to already existing research on the quality of relationships in work alliances, the present study has a clear focus on R\&D alliances. In doing so, we empirically analyzed the pathology of relations by applying a complex model of relationship constructs and, also, measured their impact on performance and alliance reformation. Until now research in this field was lacking empirical evidence (Gulati, 1998; Heimericks, 2002; Das \& Teng, 2000).

Existing research on partners' relationships had used items for measuring trust, commitment, conflict and communication (McAllister, 1995; Walter et al., 2003; Jehn \& Mannix, 2001; Mohr \& Spekman, 1994) with different samples and environments, but there was not evidence of the validity of those measures in R\&D alliances. Our study has shown that measures and factors can be valid for these alliances.

Regarding relationship structure, each construct results from existing literature and has shown high viability within the context of our research and we found that when trust, commitment, conflict and communication are higher, alliance performance reaches higher levels too.

Our findings add that communication is the most relevant factor for predicting alliance performance. This positive effect was predicted and confirmed as R\&D alliances are a kind of cooperation that usually requires transfer of knowledge (Sampton, 2007) and successful knowledge is not assured, even more when it is tacit or complex. Past research had shown that the communication behavior is related to partnership's success (Mohr \& Spekman, 1994; Anderson et al., 1987; Dwyer et al., 1987), and our study has confirmed the important role as the main predictor of alliance performance in R\&D alliances. 
Contrary to what we expected, our model found that conflict management is an important capability in R\&D alliances, taking into account that conflicts exist and that these conflicts affects the alliance performance positively. What seems to be contradictory at the first glimpse may have its origin in the diverse structure of the alliances. Different backgrounds and experiences lead to different opinions. In its positive sense, these conflicts generate new ideas, reflect creativity and contribute to the development of innovation.

To more thoroughly explicate our model, we examined factors related to alliance performance, satisfaction and reformation. Developing hypotheses from the literature on alliance performance and alliance outcomes (e.g. Das \& Teng, 2000; Kale et al., 2002; Reuer \& Zollo, 2005), we predicted and found that, in general, alliances with better performance influence in the individual satisfaction and raise the willingness to continue or to repeat the alliance experience with the existing alliance members. Therefore, satisfaction is a predictor for alliance reformation.

\subsection{Managerial Implications}

Some lesson can be extracted to be used in management practice. From the firm's point of view, this research shows the need to reinforce specific communication processes to maximize the performance and future expectations of R\&D alliances. Taken into account that R\&D activities are inherently risky (even more when they are undertaken with third parties), communication quality, information sharing, and participation (dimensions that include aspects such as the accuracy, timeliness, adequacy, and credibility of information exchanged, the extent to which critical information is communicated to partners, and the degree to which partners engage jointly in planning and goal setting) become critical for alliance organizational success. Formal common planning, joint project scheduling, and formal (systematic) communication processes among the partners are required in complex alliance such as R\&D alliances.

From the policymaker point of view, the practical implications are even more important. To be able to launch additional R\&D alliances, and to maximize the success probabilities of such complex alliances, it's a key factor to enhance their social dimensions. Building trust or commitment, improving the communication and avoiding conflicts among the partners are social challenges. In this sense, a previous social work may improve the starting conditions of the alliances. Cluster public policies, for instance, are programs aimed to strength the links and build trust between local partners. 


\subsection{Future Research}

Considering the fact that the study analyses a new database that we collected from $R \& D$ alliances on the group level (i.e. alliance performance), but addresses to individuals embedded in these alliances, multilevel research could be another statistical tool in order to address to the research topic. The contribution of multilevel research lies in a stronger consideration of the individual's environment. In other words, individual-level perceptions can be averaged to represent higher group-level situations (James \& Jones, 1976).

It could be also an interesting contribution to study, from a knowledge management perspective, if alliances that effectively reform, also have higher levels of behavior factors (trust, commitment, conflict and communication) than in previous alliances. If this case, we would empirically test a loop for alliance relationships that can drive relations upwards.

Future research on R\&D alliance relationships and performance should also look more closely at the effect of communication directly on satisfaction and reformation of the alliances, as it has been shown that it is the behavior that more increases R\&D alliance performance.

Finally, our research would be improved if we could test our model with R\&D alliance in other regions or countries to avoid that specific characteristics of the region affect the results of the study.

\section{References}

Allen, T. (1970). Communication networks in R\&D laboratories. R\&D management, 1(1), 14-21. http://dx.doi.org/10.1111/j.1467-9310.1970.tb01193.x

Anand, B, \& Khanna, T. (2000). Do firms learn to create value? The case of alliances. Strategic Management Journal, 21(3), 295-316. http://dx.doi.org/10.1002/(SICI)1097-0266(200003)21:3<295: :AID-SMJ91>3.0.CO;2-O

Amason, A., \& Sapienza, H. (1997). The effects of top management team size and interaction norms on cognitive and affective conflict. Journal of Management, 23, 496-516. http://dx.doi.org/10.1177/014920639702300401

Anderson, E., Lodish, L.M., \& Weitz, B.A. (1987). Resource allocation behavior in conventional channels. Journal of Marketing Research, 24(1), 85-97. http://dx.doi.org/10.2307/3151756

Anderson, J.C., \& Narus, J.A. (1990). A model of distributor firm and manufacturer firm working partnerships. Journal of Marketing, 54, 42-58. http://dx.doi.org/10.2307/1252172

Belderbos, R., Carree, M., \& Lokshin, B. (2004). Cooperative R\&D and firm performance. Research Policy, 33, 1477-1492. http://dx.doi.org/10.1016/j.respol.2004.07.003 
Bidault, F., \& Castello, A. (2010). Por qué el exceso de confianza es mortal para la innovación?. Harvard Deusto Business Review, 195, 24-31.

Boulding, K. (1963). Conflict and defense. New York: Harper \& Row.

Burt, R.S. (1980). Models of network structure. Annual Review of Sociology, 6, 79-141. http://dx.doi.org/10.1146/annurev.so.06.080180.000455

Butler, C. (2010). Internal and lateral communication in strategic alliance decision making. Change after several rounds of translation and re-translation. Management Decision, 48(5), 698-712. http://dx.doi.org/10.1108/00251741011043885

Clegg, C., Unsworth, K., Epitropaki, O., \& Parker, G. (2002). Implicating trust in the innovation process. Journal of Occupational and Organizational Psychology, 75, 409-422. http://dx.doi.org/10.1348/096317902321119574

Crane, D. (1969). Social structure in a group of scientists: A test of the" invisible college" hypothesis. American Sociological Review, 34(3), 335-352. http://dx.doi.org/10.2307/2092499

Cullen, J.B., Johnson, J.L., \& Sakano, T. (2000). Success through commitment and trust: The soft side of strategic alliance management. Journal of World Business, 35(3), 223-240. http://dx.doi.org/10.1016/S1090-9516(00)00036-5

Cumbers, A., Mackinnon, D., \& Chapman, K. (2003). Innovation, collaboration, and learning in regional clusters: a study of SMEs in the Aberdeen oil complex. Environment and Planning, 35(9), 1689-1706. http://dx.doi.org/10.1068/a35259

Das, T.K., \& Teng, B. (1998). Between trust and control: developing confidence in partner cooperation in alliances. Academy of Management Review, 23(3), 491-512.

Das, T.K., \& Teng, B. (2000). A Resource-Based Theory of Strategic Alliances. Journal of Management, 26(1), 31-61. http://dx.doi.org/10.1177/014920630002600105

De Jong, H., \& Woolthuis, C.M. (2008). The institutional arrangements of innovation: Antecedents and performance effects of trust in high-tech alliances. Industry and Innovation, 15, 45-67. http://dx.doi.org/10.1080/13662710701858520

Devlin, G., \& Bleackley, M. (1988). Strategic alliances-Guidelines for success. Long Range Planning, 21(5), 18-23. http://dx.doi.org/10.1016/0024-6301(88)90101-X

Dwyer, F.R., Schurr, P.H., \& Oh, S. (1987). Developing buyer - seller relationships. Journal of Marketing, 51(4), 11-27. http://dx.doi.org/10.2307/1251126

Dyer, J.H., Kale, P., \& Singh, H. (2001). How to make strategic alliances work. MIT Sloan Management Review, Summer 42(4), 37-43.

Fornell, C., Rust, R.T., \& Dekimpe, M.G. (2010). The Effect of Customer Satisfaction on Consumer Spending Growth. Journal of Marketing Research, 47(1), 28-35. http://dx.doi.org/10.1509/jmkr.47.1.28 
Ganesan, S., \& Hess, P. (1997). Dimensions and Levels of Trust: Implications for Commitment to a Relationship. Marketing Letters, 8(4), 439-448. http://dx.doi.org/10.1023/A:1007955514781

Geringer, J.M., \& Hebert, L. (1991). Measuring performance of international joint ventures. Journal of International Business Studies, 22, 249-263.

http://dx.doi.org/10.1057/palgrave.jibs.8490302

Guetzkow, H. (1965). The creative person in organizations. In G. A. Steiner (Ed.), The creative organization (pp. 35-49). Chicago: University of Chicago Press.

Gulati, R. (1998). Alliances and networks. Strategic Management Journal, 19(4), 293-317. http://dx.doi.org/10.1002/(SICI)1097-0266(199804)19:4<293: :AID-SMJ982>3.0.CO;2-M

Gundlach, G.T., Achrol, R.S., \& Mentzer, J.T. (1995). The structure of commitment in Exchange. Journal of Marketing, 59, 78-92. http://dx.doi.org/10.2307/1252016

Hagedoorn, J. (2002). Inter-firm R\&D partnerships: An overview of major trends and patterns since 196. Research Policy, 31, 477-492. http://dx.doi.org/10.1016/S0048-7333(01)00120-2

Håkansson, H. (1987). Industrial Technological Development. A Network Approach. London: Croom Helm.

Hamel, G., Doz, Y., \& Prahalad, C. (1989). Collaborate with your competitors and win. Harvard Business Review, 67(1), 133-139.

Heimericks, K. (2002). Alliance Capability, Collaboration Quality, and Alliance Performance: An Integrated Framework. Working Paper 02.05, Eindhoven Centre for Innovation Studies, The Netherlands.

Jablin, F., Putnam, L., Roberts, K., \& Porter, L. (1987). Handbook of Organizational Communication. Newbury Park: Sage Publications.

James, L.R., \& Jones, A.P. (1976). Organizational structure: A review of structural dimensions and their conceptual relationships with individual attitudes and behaviour. Organizational Behavior and Human Performance, 16, 74-113. http://dx.doi.org/10.1016/0030-5073(76)90008-8

Jehn, K. (1997). A qualitative analysis of conflict types and dimensions in organizational groups. Administrative Science Quarterly, 42, 530-557. http://dx.doi.org/10.2307/2393737

Jehn, K., \& Mannix, E. (2001). The dynamic nature of conflict: A longitudinal study of intragroup conflict and group performance. Academy of Management Journal, 44, 238-251. http://dx.doi.org/10.2307/3069453

Jehn, K., Northcraft, G., \& Neale, M. (1999). Why differences make a difference: A field study of diversity, conflict, and performance in workgroups. Administrative Science Quarterly, 44, 741-463. http://dx.doi.org/10.2307/2667054

Jiang, X., Jiang, F., Cai, X., \& Liu, H. (2015). How does trust affect alliance performance? The mediating role of resource sharing. Industrial Marketing Management, 45, 128-138. http://dx.doi.org/10.1016/j.indmarman.2015.02.011 
Joreskog, K.G. (1993). Testing structural equations models. In K.A. Bollen \& S.J. Long (Eds.), Testing structural equation models (pp. 294-316). Newbury Park: Sage Publications.

Kale, P., Dyer, J.H., \& Singh, H. (2002). Alliance capability, stock market response, and long term alliance success: The role of the alliance function. Strategic Management Journal, 23(8), 747-767. http://dx.doi.org/10.1002/smj.248

Krishnan, R., Martin, X., \& Noorderhaven, N.G. (2006). When does trust matter to alliance performance?. Academy of Management Journal, 49(5), 894-917. http://dx.doi.org/10.5465/AMJ.2006.22798171

Lane, P.J., \& Lubatkin, M. (1998). Relative absorptive capacity and interorganizational learning. Strategic Management Journal, 19, 461-477. http://dx.doi.org/10.1002/(SICI)1097-0266(199805)19:5<461: :AID-SMJ953>3.0.CO;2-L

Lengel, R.H., \& Daft, R.L. (1988). The selection of communication media as an executive skill. The Academy of Management Executive, II(3), 225. http://dx.doi.org/10.5465/AME.1988.4277259

Levin, D.Z., Cross, R. (2004). The strength of weak ties you can trust: The mediating role of trust in effective knowledge transfer. Management science, 50(11), 1477-1490. http://dx.doi.org/10.1287/mnsc.1030.0136

Lin, C., Wu, Y., Chang, C., Wang, W., \& Lee, C. (2012). The alliance innovation performance of R\&D alliances - the absorptive capacity perspective. Technovation, 32, 282-292. http://dx.doi.org/10.1016/j.technovation.2012.01.004

Luo, Y. (2008). Procedural fairness and interfirm cooperation in strategic alliances. Strategic Management Journal, 29(1), 27-46. http://dx.doi.org/10.1002/smj.646

Luo, X., Homburg, C., \& Wieseke, J. (2010). Customer Satisfaction, Analyst Stock Recommendations, and Firm Value. Journal of Marketing Research, 47(6), 1041-1058. http://dx.doi.org/10.1509/jmkr.47.6.1041

Malik, M.J., Ahmad, M., Saif, M.J., \& Safwan, M.N. (2010). Relationship of organizational commitment, job satisfaction and layoff survivors' productivity. Interdisciplinary Journal of Contemporary Research in Business, 2(7), 200-211.

Maurer, I. (2010). How to build trust in inter-organizational projects: The impact of project staffing and project rewards on the formation of trust, knowledge acquisition and product innovation. International Journal of Project Management, 28(7), 629-637.

http://dx.doi.org/10.1016/j.ijproman.2009.11.006

McAllister, D.J. (1995). Affect- and cognition-based trust as foundations for interpersonal cooperation in organizations. Academy of Management Journal, 38(1), 24-59. http://dx.doi.org/10.2307/256727

Merchant, H., \& Schendel, D. (2000). How do international joint ventures create shareholder value?. Strategic Management Journal, 21(7), 723-738. http://dx.doi.org/10.1002/10970266(200007)21:7<723: :AID-SMJ114>3.0.CO;2-H 
Mohr, J., \& Spekman, R. (1994). Characteristics of partnership success: partnership attributes, communication behavior, and conflict resolution techniques. Strategic Management Journal, 15(2), 135-152. http://dx.doi.org/10.1002/smj.4250150205

Morgan, R.M., \& Hunt, S.D. (1994). The commitment-trust theory of relationship marketing. Journal of Marketing, 58, 20-38. http://dx.doi.org/10.2307/1252308

Morris, B., \& Cadogan, J. (2001). Partner Symmetries, Partner Conflict and the Quality of Joint Venture Marketing Strategy: An Empirical Investigation. Journal of Marketing Management, 17, 223-256. http://dx.doi.org/10.1362/0267257012571474

Nakos, G., \& Brouthers, K.D. (2008). International alliance commitment and performance of small and medium-size enterprises: The mediating role of process control. Journal of International Management, 14, 124-137. http://dx.doi.org/10.1016/j.intman.2007.11.001

Nielsen, B., \& Nielsen, S. (2009). Learning and Innovation in International Strategic Alliances: An Empirical Test of the Role of Trust and Tacitness. Journal of Management Studies, 46(6), 1031-1056. http://dx.doi.org/10.1111/j.1467-6486.2009.00840.x

Oliver, R.L. (1996). Satisfaction. A Behavioral Perspective on the Consumer. New York, McGraw-Hill.

Panayides, P.M., \& Venus Lun, Y.H. (2009). The impact of trust on innovativeness and supply chain performance. International Journal of Production Economics, 122(1), 35-46. http://dx.doi.org/10.1016/j.ijpe.2008.12.025

Perry, M.L., Sengupta, S., \& Krapfel, R. (2004). Effectiveness of horizontal strategic alliances in technologically uncertain environments: Are trust and commitment enough?. Journal of Business Research, 57(9), 951-956. http://dx.doi.org/10.1016/S0148-2963(02)00501-5

Powell, P.W., Koput, K.W., \& Smith-Doerr, L. (1996). Interorganizational collaboration and the locus of control of innovation: Networks of learning in biotechnology. Administrative Science Quarterly, 41, 116-145. http://dx.doi.org/10.2307/2393988

Porter, M.E. (1990). The competitive advantage of nations. New York: Free Press.

Price, D.J.S., \& Beaver, D. (1966). Collaboration in an invisible college. American Psychologist, 21(11), 1011-1018. http://dx.doi.org/10.1037/h0024051

Reuer, J., \& Zollo, M. (2005). Termination outcomes of research alliances. Research Policy, 34, 101-115. http://dx.doi.org/10.1016/j.respol.2004.11.003

Reve, T., \& Stem, L.W. (1979). Interorganizational relations in marketing channels. Academy of Management Review, 4, 405-416.

Rogers, E. (1995). Diffusion of Innovations (4th ed.). New York, Free Press.

Sampton, R.C. (2007). R\&D alliances and firm performance: the impact of technological diversity and alliance organization on innovation. Academy of Management Journal, 50(2), 364-386. http://dx.doi.org/10.5465/AMJ.2007.24634443 
Saxton, T. (1997). The effects of partner and relationship characteristics on alliance outcomes. Academy of Management Journal, 40(2), 443-461. http://dx.doi.org/10.2307/256890

Schuler, R. (1979). A role perception transactional process model for organizational communication- outcome relationships. Organizational Behavior and Human Performance, 23, 268-291. http://dx.doi.org/10.1016/0030-5073(79)90058-8

Sharma, J.P., Bajpai, N., \& Holani, U. (2011). Organizational citizenship behavior in public and private sector and its impact of job satisfaction: A comparative study in Indian perspective. Journal of Business and Management, 6(1), 67-75.

Sheth, J., \& Parvatiyar, A. (1992). Towards a theory of business alliance formation. Scandinavian International Business Review, 1(3), 71-87. http://dx.doi.org/10.1016/09629262(92)90012-U

Shipton, H.J., West, M.A., Parkes, C.L., Dawson, J.F., \& Patterson, M.G. (2006). When promoting positive feelings pays: Aggregate job satisfaction, work design features, and innovation in manufacturing organizations. European Journal of Work and Organizational Psychology, 15(4), 404-430. http://dx.doi.org/10.1080/13594320600908153

Singh, A.P., \& Dubey, A.K. (2011). Role of stress and locus of control in job satisfaction among middle managers. Journal of Organizational Behaviour, 10(1), 42-56.

Stohl, C., \& Redding, W.C. (1987). Messages and message exchange processes. In F. Jablin, L. Putman, K. Roberts, \& L. Porter (Eds.), Handbook of organizational communication (pp. 451-502). Newbury Park: Sage.

Suseno, Y., \& Ratten, V. (2007). A theoretical framework of alliance performance: the role of trust, social capital and knowledge development. Journal of Management \& Organization, 13(1), 4-23. http://dx.doi.org/10.5172/jmo.2007.13.1.4

Tyler, B.B., \& Steensma, H.K. (1995). Evaluating technological collaborative opportunities: A cognitive modelling perspective. Strategic Management Journal, 16, 43-70.

http://dx.doi.org/10.1002/smj.4250160917

Van der Vegt, G.S., Emans, B.J.M., \& Van de Vliert, E. (2001). Patterns of interdependence in work teams: A two-level investigation of the relations with job and team satisfaction. Personnel Psychology, 54, 51-69. http://dx.doi.org/10.1111/j.1744-6570.2001.tb00085.x

Walter, A., Muller, T., Helfert, G., \& Ritter, T. (2003). Functions of industrial supplier relationships and their impact on relationship quality. Industrial Marketing Management, 32, 159-169. http://dx.doi.org/10.1016/S0019-8501(02)00230-4

Wang, T.C., \& Chen, Y.H. (2007). Applying consistent fuzzy preference relations to partnership selection. Omega, 35(4), 384-388. http://dx.doi.org/10.1016/j.omega.2005.07.007

Williamson, O.E. (1985). The economic institutions of capitalism. New York: Free Press. 
Wu, F., \& Cavusgil, T. (2006). Organizational learning, commitment, and joint value creation in interfirm relationships. Journal of Business Research, 59, 81-89.

http://dx.doi.org/10.1016/j.jbusres.2005.03.005

Yi, H.T., Lee, J., \& Dubinsky, A.J. (2010). An Empirical Investigation of Relational Conflicts in Co-Marketing Alliances. Journal of Business-to-Business Marketing, 17, 249-278. http://dx.doi.org/10.1080/10517120903465350

Zollo, M., Reuer, L., \& Singh, H. (2002). Interorganizational routines and performance in strategic alliances. Organization Science, 3(6), 701-713.

http://dx.doi.org/10.1287/orsc.13.6.701.503

Journal of Industrial Engineering and Management, 2015 (www.jiem.org)

(C)

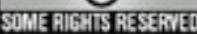

Article's contents are provided on an Attribution-Non Commercial 3.0 Creative commons license. Readers are allowed to copy, distribute and communicate article's contents, provided the author's and Journal of Industrial Engineering and Management's names are included. It must not be used for commercial purposes. To see the complete license contents, please visit http://creativecommons.org/licenses/by-nc/3.0/. 